\title{
A Model of U.S. Monetary Policy Before and After the Great Recession
}

David Andolfatto

The author studies a simple dynamic general equilibrium monetary model to interpret key macroeconomic developments in the U.S. economy both before and after the Great Recession. In normal times, when the Federal Reserve's policy rate is above the interest paid on reserves, countercyclical monetary policy works in a textbook manner. When a shock drives the policy rate to the zero lower bound, the economy enters a liquidity-trap scenario in which open market purchases of government securities have no real or nominal effects, apart from expanding the supply of excess reserves in the banking sector. In a liquidity trap, the Fed loses all control of inflation, which is now determined entirely by the fiscal authority. In normal times, raising the interest paid on reserves stimulates economic activity, but in a liquidity trap, raising the interest paid on reserves retards economic activity. (JEL E4, E5)

Federal Reserve Bank of St. Louis Review, Third Quarter 2015, 97(3), pp. 233-56.

$\mathbf{T}$ he Great Recession of 2007-09 and its aftermath ushered in a new era for U.S. monetary policy. Prior to 2008, the Federal Reserve's policy rate stood in excess of 500 basis points. In 2008, the policy rate declined rapidly to 25 basis points, where it has remained ever since. Prior to 2008, the Fed's balance sheet stood at less than $\$ 1$ trillion dollars-about 7 percent of gross domestic product (GDP). Fed security holdings and liabilities are presently near $\$ 4.5$ trillion dollars-about 25 percent of GDP. Most of these liabilities exist as excess reserves in the banking system. Prior to 2008, excess reserves were essentially zero. The situation is so unusual that commentators frequently describe the Fed as sailing in uncharted waters.

The U.S. economy has recovered steadily, if somewhat slowly, since the end of the Great Recession. After peaking at over 10 percent in 2009, the civilian unemployment rate at the time this article was written was close to 5.5 percent. Despite the more than fourfold increase in the supply of base money, personal consumption expenditures (PCE) inflation undershot the Fed's 2 percent target throughout much of the recovery. With inflation varying between

David Andolfatto is a vice president and economist at the Federal Reserve Bank of St. Louis. The author thanks Costas Azariadis, Alexander MongeNaranjo, and Steve Williamson for their comments and criticisms; Michael Varley for his research assistance; and Fernando Martin for many useful discussions.

(C) 2015, Federal Reserve Bank of St. Louis. The views expressed in this article are those of the author(s) and do not necessarily reflect the views of the Federal Reserve System, the Board of Governors, or the regional Federal Reserve Banks. Articles may be reprinted, reproduced, published, distributed, displayed, and transmitted in their entirety if copyright notice, author name(s), and full citation are included. Abstracts, synopses, and other derivative works may be made only with prior written permission of the Federal Reserve Bank of St. Louis. 


\section{Andolfatto}

50 and 100 basis points below target and the labor market continuing to improve, the Fed has recently announced its willingness - some might say eagerness - to raise its policy rate as economic conditions dictate. Speculation over the date at which liftoff will occur is rampant in the financial pages of newspapers, as is concern over the wisdom of raising rates prematurely or leaving rates too low for too long.

People have many questions concerning the economic developments and issues just described. Why did interest rates plummet so dramatically in 2008? Why did the massive increase in base money appear to have no noticeable effect on the price level or inflation? Does the fact that most of this new money sits as excess reserves in the banking system portend an impending inflationary episode — an event that the Fed might have trouble controlling? Or will inflation continue to drift lower as interest rates remain low, replicating the experience of Japan over the past two decades? What, if anything, can or should the Fed do in present circumstances?

I answer these (and other) questions through the lens of a simple dynamic general equilibrium model that features three assets: money, bonds, and capital. In the model, money is dominated in rate of return but is nevertheless held to satisfy an exogenous demand for liquidity, modeled here as a legal reserve requirement. This reserve requirement binds when the nominal interest rate on bonds exceeds the interest paid on money. Excess reserves are held willingly when the nominal interest rates on bonds and money are the same. When this latter condition holds, the economy is in a liquidity trap. Open market purchases of bonds have no real or nominal effects, apart from increasing reserves in excess of the statutory minimum.

I demonstrate how the model can be used to interpret the effect of open market operations in normal times-defined as episodes in which money is dominated in rate of return and excess reserves are zero. An open market purchase of securities in this case has the effect of expanding the supply of liquidity in the economy, making it easier for banks and other entities to fulfill their reserve requirements. The policy rate (the interest rate on bonds) declines and the price level rises. As desired capital spending expands, banks increase their loan activity. There is no effect on long-run inflation when the inflation rate is anchored by fiscal policy.

I then consider a negative aggregate demand shock - technically, a news shock (Beaudry and Portier, 2014) - that leads agents to revise downward their forecasts over the future productivity of (or after-tax return on) contemporaneous capital spending. Ceteris paribus, the effect of such a shock is to induce a portfolio substitution away from capital and into government securities (money and bonds), placing downward pressure on bond yields and the price level. An open market purchase at this point places additional downward pressure on bond yields, stimulating investment and placing upward pressure on the price level. In this way, the monetary authority stabilizes both real economic activity and the price level.

When a negative aggregate demand shock is severe, the consequent decline in desired investment spending places significant downward pressure on bond yields as investors pursue a flight to safety, moving away from capital and into government securities. While the Fed can try its usual countercyclical measures at this point, the endeavor is ultimately stymied if its policy rate falls to the interest paid on reserves (usually zero, but presently 25 basis points). Additional open market operations at this stage have no effect on either real or nominal vari- 
ables, apart from expanding the quantity of excess reserves. I argue that, to a first approximation, this is the reason the Fed's post-2008 quantitative easing (QE) programs appear to have had very little economic impact, apart from expanding the supply of excess reserves in the banking system. ${ }^{1}$

While conventional open market operations are inoperative in a liquidity-trap situation, the Fed may still influence real economic activity through the interest it pays on excess reservesthe so-called IOER rate. The effect of altering the interest rate on reserves in a liquidity trap is very different from the effect it is likely to have in normal times. In normal times, banks wish to minimize their cash reserves because the yield on cash is low relative to competing investments. Lowering the interest rate on reserves increases the implicit tax on reserves, which reduces the demand for reserves, leading to a constraint on bank lending and investment. In a liquidity trap, banks willingly hold excess reserves and the same operation lowers the yield on all government debt, leading to a portfolio substitution away from government debt into private investment.

Finally, I demonstrate how a central bank theoretically loses all control over inflation in a liquidity trap. In this case, inflation is determined exclusively by the fiscal authority-in particular, by the growth rate of nominal debt (relative to the growth in its demand). If the fiscal authority supplies debt passively to meet market demand, the model implies a real indeterminacy: The economy can get stuck at any number of subnormal levels of economic activity, depending on which self-fulfilling inflation rate transpires. Determinacy is restored when the fiscal authority anchors the inflation rate by expanding the supply of debt on its own schedule and not in accordance with market demands.

\section{THE MODEL ECONOMY}

\section{Preferences and Technology}

In what follows, I describe a variant of Samuelson's (1958) overlapping-generations model, similar to the one developed in Andolfatto (2003). Time is discrete and the horizon is infinite, $t=1,2, \ldots, \infty$. At each date $t \geq 1$, a unit mass of young agents enter the economy and a unit mass of old agents leave the economy. Apart from an initial unit mass of old agents (who live only for one period), each generation of young agents lives for two consecutive periods. The total population is therefore fixed across time and is at every date $t$ divided evenly between the young and old. A young person at date $t$ becomes an old person at date $t+1$.

Agents of every generation $t \geq 1$ are endowed with $y$ units of output when young and zero units of output when old. Individuals are assumed to value consumption only in their old age. Consequently, the young face a trivial consumption-saving decision: It will always be optimal for them to save their entire income. The simplified consumption-saving choice permits me to focus on portfolio allocation decisions, the mechanism I wish to emphasize later. For simplicity, I also assume that preferences are linear.

Each young agent has access to an investment opportunity where $k_{t}$ units of output invested at date $t$ yield $x f\left(k_{t}\right)$ units of output at date $t+1$, where $x>0$ is an exogenous productivity 
parameter that governs the expected return to investment. Assume that the production function $f$ satisfies $f^{\prime \prime}(k)<0<f^{\prime}(k)$; that is, higher levels of investment generate higher levels of future output, but with diminishing returns to scale. As well, assume that $f^{\prime}(0)=\infty$ so that some investment will always be optimal. Finally, assume that capital depreciates fully after it is used in production.

\section{Welfare}

The competitive equilibrium of this economy is autarkic-that is, $k_{t}=y$ for all $t$. If $x f^{\prime}(y)<1$, the economy is dynamically inefficient (the competitive equilibrium real interest rate is less than the population growth rate). As such, there is a welfare-enhancing role for government debt. As is well known, the golden rule allocation can be implemented as a competitive monetary equilibrium with a perpetually fixed stock of government debt (although, as we shall see below, one needs to worry about the stability properties of such an equilibrium).

The policy of maintaining a fixed quantity of nominal debt continues to remain optimal here even if, say, $x$ were to follow a stochastic process because of my assumption of linear (risk-neutral) preferences. Generalizing the model to nonlinear preferences would, in this case, imply a role for state-contingent interventions essentially for the purpose of completing a missing intergenerational insurance market. I am reluctant to generalize the analysis in this manner, however, because the main points I wish to stress can be demonstrated much more cleanly in a linear world.

Apart from the desirability of government debt when $x f^{\prime}(y)<1$, the analysis below offers no welfare rationale for the policies examined. For example, I assume the existence of two forms of government debt, money and bonds, even though the model provides no theoretical rationale for two distinct forms of debt. Moreover, I assume that the government issues money and debt even in the case $x f^{\prime}(y)>1$. I also follow conventional practice in assuming exogenous government policy rules.

\section{Government Policy}

There are two nominal assets, money $M_{t}$ and bonds $B_{t}$, each issued by the government. Bonds yield a gross nominal one-period (from $t$ to $t+1$ ) yield denoted by $R_{t}^{b}$. I assume that money can potentially earn interest at rate $R_{t}^{m}$ (think of this as interest paid on reserves). For simplicity, I set government purchases to zero. The interest and principal owed on maturing government debt $R_{t-1}^{m} M_{t-1}+R_{t-1}^{b} B_{t-1}$ must be financed by a combination of new debt and a lump-sum tax $T_{t}$; that is,

$$
R_{t-1}^{m} M_{t-1}+R_{t-1}^{b} B_{t-1}=T_{t}+M_{t}+B_{t} .
$$

Let $D_{t}$ denote the nominal value of the government's total outstanding debt at date $t$; that is, $D_{t}=M_{t}+B_{t}$. In what follows, I assume that the fiscal authority determines the path of $D_{t}$ and $T_{t}$, and I assume that the monetary authority determines the path of interest rates $R_{t}^{m}, R_{t}^{b}$ along with the composition of the total debt $\theta_{t}=M_{t} / D_{t}$. Condition (1) shows explicitly how monetary and fiscal policy are interlinked through the government budget constraint. 
Fiscal policy operates as follows. First, I assume that the fiscal authority grows the nominal debt at a fixed rate $\mu$, so that,

$$
D_{t}=\mu D_{t-1},
$$

with the initial debt $D_{0}>0$ endowed to the initial old. With interest rates and debt composition determined by monetary policy, I assume that the fiscal authority passively adjusts the lumpsum tax $T_{t}$ to satisfy the government budget constraint (1).

Because it will prove convenient to express variables in real terms, let $p_{t}$ denote the date- $t$ price level and define $\tau_{t}=T_{t} / p_{t}, d_{t}=D_{t} / p_{t}$. Using (2) and $\theta_{t}=M_{t} / D_{t}$, rewrite the government budget constraint (1) as follows:

$$
\tau_{t}=\left[\frac{R_{t-1}^{m} \theta_{t-1}+R_{t-1}^{b}\left(1-\theta_{t-1}\right)}{\mu}-1\right] d_{t} .
$$

In what follows, I assume that the tax $\tau_{t}$ (or transfer, if negative) falls entirely on the old at date $t^{2}$

Since money and bonds share identical risk and liquidity characteristics in the setup considered here, to motivate a demand for money when it is dominated in rate of return (i.e., when $R_{t}^{b}>R_{t}^{m}$ ) I assume that individuals are subject to a legal minimum reserve requirement. I specify the exact nature of this reserve requirement when I later describe individual decisionmaking.

With fiscal (and regulatory) policy set in the manner described earlier, I turn attention to investigating the properties of alternative monetary policies. In all of the monetary policies considered below, I assume that interest on reserves is set exogenously to some level $R^{m}$. In most models, it is assumed that money exists in the form of zero interest cash, so that $R^{m}=1$. In the upcoming analysis, $R^{m} \gtrless 1$ is permitted, which suggests interpreting the relevant money supply as electronic central bank reserves. ${ }^{3}$

I consider three different monetary policy regimes. First, I model an interest rate peg $R_{t}^{b}=R^{b} \geq R^{m}$, where $\theta$ is determined by market forces. Second, I model a money-to-debt ratio peg $\theta_{t}=\theta$, where $R^{b}$ is determined by market forces. Third, I consider a more general interest rate rule along the lines of Taylor (1993).

\section{Decisionmaking}

A young person is endowed with $y$ units of real income. Since consumption is not valued when young, all income is saved, with savings divided among the three available assets: money $\left(m_{t}\right)$, bonds $\left(b_{t}\right)$, and capital $\left(k_{t}\right)$. Thus,

$$
y=m_{t}+b_{t}+k_{t}
$$

where $m_{t}, b_{t}$ denote real money and bond holdings, respectively. Given a portfolio choice, future (old age) consumption is denoted by

$$
c_{t+1}=x f\left(k_{t}\right)+R_{t}^{b}\left(p_{t} / p_{t+1}\right) b_{t}+R^{m}\left(p_{t} / p_{t+1}\right) m_{t}-\tau_{t+1} .
$$


Following Smith (1991), I assume that individuals must hold a minimum amount of cash reserves against their capital holdings; in particular,

$$
m_{t} \geq \sigma k_{t}
$$

where $0<\sigma<1$ is an exogenous policy parameter. Much of what follows depends on whether the reserve requirement constraint is binding.

The reserve requirement (6) may seem peculiar because it appears to require agents to hold reserves against assets rather than liabilities. But as pointed out by Smith (1991), it is possible to map this specification into something that looks more realistic by reinterpreting the model in an appropriate way. Suppose, for example, that after acquiring the portfolio $y=m_{t}+b_{t}+k_{t}$, the young find it convenient to deposit $p_{t}\left[m_{t}+k_{t}\right]$ dollars in a bank (consisting of a coalition of young agents). The bank issues liabilities of equivalent value-that is, $p_{t}\left[m_{t}+k_{t}\right]$ dollars that are redeemable for a future monetary value of $p_{t+1}\left[x f\left(k_{t}\right)+R^{m} p_{t} m_{t}\right]$ dollars. A more realistic reserve requirement specifies that a minimum fraction $\xi$ of bank liabilities $p_{t}\left[m_{t}+k_{t}\right]$ needs to be held as cash—that is, $p_{t} m_{t} \geq \xi p_{t}\left[m_{t}+k_{t}\right]$. If we define $\sigma \equiv \xi /(1-\xi)$, then this more realistic reserve requirement corresponds exactly to (6). The representation in (4)-(6) then simply consolidates the balance sheet of banks and their depositors. ${ }^{4}$

Let us now characterize optimal behavior. Substitute (4) into (5) and form the expression

$$
W_{t}=x f\left(k_{t}\right)+R_{t}^{b}\left(p_{t} / p_{t+1}\right)\left[y-m_{t}-k_{t}\right]+R^{m}\left(p_{t} / p_{t+1}\right) m_{t}-\tau_{t+1}+\lambda_{t}\left[m_{t}-\sigma k_{t}\right]
$$

where $\lambda_{t} \geq 0$ is the Lagrange multiplier associated with the reserve requirement. Maximizing $W_{t}$ (expected future wealth/consumption) with respect to $m_{t}$ and $k_{t}$ yields the following restrictions:

$$
\begin{array}{ccc}
\lambda_{t} & = & \left(R_{t}^{b}-R^{m}\right)\left(p_{t} / p_{t+1}\right) \\
R_{t}^{b}\left(p_{t} / p_{t+1}\right) & = & x f^{\prime}\left(k_{t}\right)-\sigma \lambda_{t}
\end{array} .
$$

Condition (7) makes clear that the reserve requirement will bind tightly $\left(\lambda_{t}>0\right)$ if and only if bonds strictly dominate money in rate of return $\left(R_{t}^{b}>R^{m}\right)$. If money cannot earn interest $\left(R^{m} \geq 1\right)$ and if money does not earn interest $\left(R^{m}=1\right)$, then one could say that the reserve requirement binds tightly only when the economy is away from the zero lower bound (ZLB).

Condition (8) implicitly defines the demand for investment. This condition shows that the expected rate of return on capital spending exceeds (equals) the return on bonds when the reserve requirement binds (is slack). That is, when the reserve requirement binds, agents would prefer to expand their capital spending, since the return from doing so is higher than investing in bonds. But doing so means accumulating additional low-return cash. Hence, the reserve requirement serves as a tax on capital spending, and condition (8) equates the after-tax returns on capital and bonds.

Combine conditions (7) and (8) to form 


$$
x f^{\prime}\left(k_{t}\right)=\left[(1+\sigma) R_{t}^{b}-\sigma R^{m}\right]\left(p_{t} / p_{t+1}\right)
$$

Condition (9) characterizes investment demand $k_{t}$. This condition holds regardless of whether the reserve requirement binds. The demand for government assets is left to be determined. If $R_{t}^{b}>R^{m}$, then the demand for real money balances is given by $m_{t}=\sigma k_{t}$. That is, the demand for reserves is proportional to the demand for investment. The demand for bonds can then be determined residually from condition (4) as $b_{t}=y-m_{t}-k_{t}$.

When the reserve requirement is slack, money and bonds are viewed as perfect substitutes in individual wealth portfolios. With $k_{t}$ determined by condition (9), the demand for government assets is well defined and given by $d_{t}=y_{t}-k_{t}$. But the individual demand for money and bonds is indeterminate. That is, any combination of $m_{t}, b_{t}$ satisfying $m_{t} \geq \sigma k_{t}$ and $m_{t}+b_{t}=d_{t}$ is consistent with individual optimization. The implication here is that the demand for money and bonds will, in this case, accommodate itself to the respective supply of money and bonds without the need for any price adjustment.

Proposition 1 The investment demand function $k_{t}$ characterized by condition (9) is increasing in (i) the expected return to capital investment ( $x$ ); (ii) the expected rate of inflation $\left(p_{t+1} / p_{t}\right)$; and (iii) the interest rate on reserves $\left(R^{m}\right)$. Investment demand is decreasing in the nominal yield on bonds $\left(R_{t}^{b}\right)$.

The proof of this proposition follows immediately from condition (9). Intuitively, an increase in $x$ increases the expected productivity of capital and so stimulates capital spending. An increase in the expected rate of inflation reduces the real interest rate on competing nominal assets, stimulating a portfolio substitution away from these assets and into capital. It is worth emphasizing the effect on investment demand from an increase in the interest rate. Proposition 1 asserts that the answer depends on exactly which interest rate one is referring to. An increase in the interest rate on bonds has the effect here of reducing investment demandagents substitute out of capital and into higher-yielding government securities. An increase in the interest rate on reserves, however, has the effect of stimulating investment demand. An increase in the interest rate on reserves lowers the cost of holding reserves, so agents are motivated to expand their holdings of reserves, which then permits capital spending to increase. ${ }^{5}$

\section{EQUILIBRIUM}

In any equilibrium, we have $M_{t}=p_{t} m_{t}, B_{t}=p_{t} b_{t}$, and $D_{t}=p_{t} d_{t}$. Because $D_{t}=\mu D_{t-1}$, the expected rate of inflation must satisfy

$$
\Pi_{t+1} \equiv\left(\frac{p_{t+1}}{p_{t}}\right)=\left(\frac{D_{t+1}}{D_{t}}\right)\left(\frac{d_{t}}{d_{t+1}}\right)=\mu\left(\frac{d_{t}}{d_{t+1}}\right) .
$$

Now, combine (10) and (9) together with $k_{t}=y-k_{t}$ to form

$$
x f^{\prime}\left(y-d_{t}\right)=\left[\frac{(1+\sigma) R_{t}^{b}-\sigma R^{m}}{\mu}\right]\left(\frac{d_{t+1}}{d_{t}}\right) .
$$


Recall that $\theta_{t} \equiv M_{t} / D_{t}=m_{t} / d_{t}$. If the reserve requirement binds $\left(R_{t}^{b}>R^{m}\right)$, then $\theta_{t}=\sigma\left(y-d_{t}\right) / d_{t}$, which when expressed in terms of $d_{t}$, becomes

$$
d_{t}=\left(\frac{\sigma}{\theta_{t}+\sigma}\right) y .
$$

If the reserve requirement is slack $\left(R_{t}^{b}=R^{m}\right)$, then condition (12) can be ignored (since the composition of debt $\theta_{t}$ is irrelevant in this case). From the government budget constraint (3), we have

$$
\tau_{t}=\left[\frac{R^{m} \theta_{t-1}+R_{t-1}^{b}\left(1-\theta_{t-1}\right)}{\mu}-1\right] d_{t} .
$$

\section{Interest Rate Peg}

The first type of monetary policy I want to study is an interest rate peg: $R_{t}^{b}=R^{b}>R^{m}$. An equilibrium in this case consists of bounded sequences for $d_{t}$, $\tau_{t}$, and $\theta_{t}$ that satisfy (11)-(13) for all $t \geq 1$. A stationary equilibrium is an equilibrium that satisfies $\left(d_{t}, \tau_{t}, \theta_{t}\right)=(d, \tau, \theta)$ for all $t$.

Note that the equilibrium here has a recursive structure. That is, condition (11) determines $\left\{d_{t}\right\}_{t=1}^{\infty}$. With $d_{t}$ so determined, condition (12) determines the sequence of open market operations $\left\{\theta_{t}\right\}_{t=1}^{\infty}$ that are necessary to support the fixed interest rate regime. With $\left\{d_{t}, \theta_{t}\right\}$ so determined, condition (13) then determines the lump-sum tax $\tau_{t}$ that is necessary to balance the government budget.

Define $A^{-1} \equiv\left[(1+\sigma) R^{b}-\sigma R^{m}\right] / \mu>0$ and rewrite (11) as

$$
d_{t+1}=A x f^{\prime}\left(y-d_{t}\right) d_{t} \equiv P\left(d_{t}\right)
$$

From (14), we see that conditional on a policy $\left(R^{b}, R^{m}, \mu\right)$, two stationary equilibria are possible, one of which is degenerate $(d=0)$ and the other of which satisfies $1=A x f^{\prime}\left(y-d^{*}\right)$ with $0<d^{*}<\infty$ (point A in Figure 1). Given the strict concavity of $f$, the nondegenerate stationary equilibrium is unique. ${ }^{6}$

Let me now investigate the stability properties of these two stationary states. First, note that $P^{\prime}(d)=A x\left[f^{\prime}(y-d)-f^{\prime \prime}(y-d) d\right] \geq 0$, with $P^{\prime}(0)=0$ and $P^{\prime}(d)>0$ for $d>0$. Thus, $P(d)$ is increasing monotonically in $d$. Second, note that $\lim _{d \rightarrow 0} P(d) / d=P^{\prime}(0)=0$ and $\lim _{d \rightarrow y} P(d) / d=$ $P^{\prime}(y)=\infty$, so that $P(d)$ takes the general shape displayed in Figure 1, crossing the 45 -degree line twice: once at the origin and once at point $\mathrm{A}$.

The properties of $P(d)$ are familiar in overlapping-generations models of fiat money, where money is the only asset and whose nominal return is pegged (usually to zero). Under an interest rate peg then, there exists a continuum of nonstationary equilibria indexed by an arbitrary initial condition $d_{1} \in(0, d)$ with the property that $d_{t} \rightarrow 0 .{ }^{7}$ Equilibria of this form are hyperinflations, where the value of nominal government debt eventually approaches zero. ${ }^{8}$ Since $d_{1}=D_{1} / p_{1}$, the multiplicity of nonstationary equilibria implies that the initial price level is indeterminate.

The nondegenerate steady-state $0<k^{*}<y$ is characterized by 


\section{Figure 1}

\section{Equilibrium Dynamics (Interest Rate Peg)}

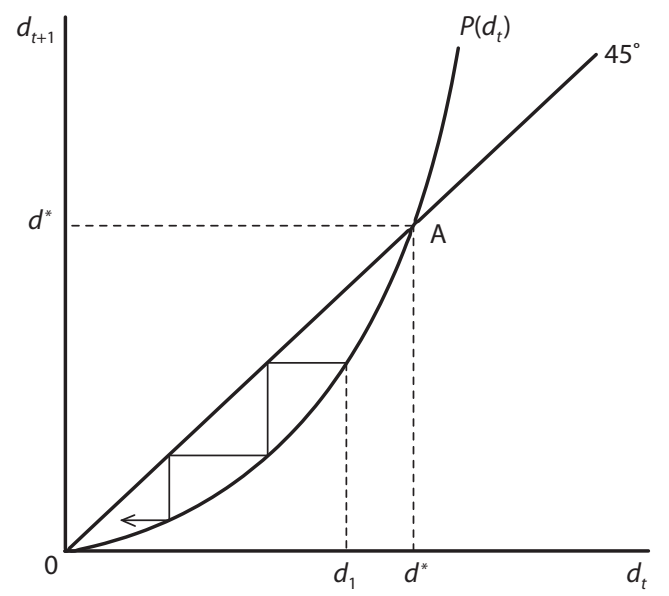

$$
x f^{\prime}\left(k^{*}\right)=\left[\frac{(1+\sigma) R^{b}-\sigma R^{m}}{\mu}\right] .
$$

Although $k^{*}$ is unstable under the interest rate target rule, we can still make statements on how it depends on parameters.

Proposition 2 If $R^{b}>R^{m}$, then $k^{*}$ is increasing in $x, \mu$, and $R^{m}$ and is decreasing in $R^{b}$.

To prove this, define $g(k) \equiv f^{\prime}(k)(y-k)$ and note that $g^{\prime}(k)=(y-k) f^{\prime \prime}(k)-f^{\prime}(k) k<0$. Intuitively, an increase in $x$ increases the return on (and hence the demand for) capital. An increase in the inflation rate $\mu$ lowers the real return on government bonds, inducing a portfolio substitution away from bonds and into capital (and into money as well, to meet the reserve requirement). An increase in the interest rate on reserves, however, has the effect of stimulating capital spending here because it lowers the tax on holding money.

Under the policy regime described here, different policy rates $R^{b}$ are associated with different money-to-debt ratios $\theta$. In particular, from condition (12) $\theta=\sigma k /(y-k)$, so that $\theta$ is increasing in $k$. From Proposition 2 then, a higher $R^{b}$ is associated with a lower $\theta$ (a tighter monetary policy). As well, since $p_{t}=D_{t} /(y-k)$, a higher $R^{b}$ is associated with a lower price level, although note that the long-run inflation rate remains pinned by $\mu$.

While the nondegenerate steady state is unstable under this policy regime, it turns out to be stable under the policy regime considered next.

\section{Money-to-Debt Ratio Peg}

The second type of monetary policy I want to study is a money-to-debt peg: $\theta_{t}=\theta>0$. An equilibrium in this case consists of bounded sequences for $d_{t}, \tau_{t}$, and $R_{t}^{b}$ that satisfy (11)-(13) 
for all $t \geq 1$. A stationary equilibrium is an equilibrium that satisfies $\left(d_{t}, \tau_{t}, R_{t}^{b}\right)=\left(d, \tau, R^{b}\right)$ for all $t$.

When the reserve requirement binds $\left(R_{t}^{b}>R^{m}\right)$, condition (12) determines the real quantity of government debt $d=(\sigma /(\theta+\sigma)) y$ and the equilibrium level of capital spending $k=$ $y-d=(\theta /(\theta+\sigma)) y$. The implication of this is that the price level is now determinate, $p_{t}=D_{t} / d$ for all $t \geq 1$. Moreover, because $d_{t}=d$ for all $t \geq 1$, there are no nonstationary equilibria. The policy of pegging $\theta$ instead of $R^{b}$ results in a unique equilibrium that is also a stationary equilibrium (as long as $R^{b}>R^{m}$ ).

Use (11) and (12) together with $\theta_{t}=\theta$ to derive this expression for the equilibrium bond yield,

$$
R^{b}=(1+\sigma)^{-1}\left[\mu x f^{\prime}\left(\left(\frac{\theta}{\theta+\sigma}\right) y\right)+\sigma R^{m}\right]>R^{m} .
$$

Proposition 3 If $R^{b}>R^{m}$, then the equilibrium nominal bond yield $R^{b}$ is strictly increasing in $x$ and strictly decreasing in $\theta$. The equilibrium level of capital spending $k$ is increasing in $x$ and $\theta$.

This proposition is easily validated by inspecting (16). The intuition is straightforward. An increase in $x$ leads to an upward revision in the forecasted return to capital spendingthat is, there is an increase in the demand for investment at any given interest rate. Agents are motivated to substitute out of bonds and into capital. But policy here pins down the real value of the outstanding supply of bonds. The decline in bond demand must therefore be fully absorbed as a decline in the price of bonds - that is, the bond yield-must rise.

An increase in $\theta$ corresponds to a (permanent) open market operation that expands the supply of cash relative to bonds. The added supply of reserves permits agents to expand capital spending. But as capital spending expands, the rate of return to capital declines (the marginal product of capital is diminishing). As capital investment becomes relatively unattractive at the margin, agents are induced to substitute into bonds, increasing their price (lowering their yield).

Proposition 3 together with (16) implies that there exists a number $\hat{x}>0$ such that

$$
R^{b}=\mu \hat{x} f^{\prime}\left(\left(\frac{\theta}{\theta+\sigma}\right) y\right)=R^{m} .
$$

When $R^{b}=R^{m}$, the reserve requirement is slack. Thus, for a given configuration of policy parameters $\left(\theta, \mu, R^{m}\right)$, a sufficiently bad shock $(x<\hat{x})$ will drive bond yields to their lower bound (the interest rate paid on reserves). For $x<\hat{x}$, the stationary value of real debt $(d)$ is no longer determined by (12); it is instead determined by (11),

$$
R^{m}=\mu x f^{\prime}(y-d)
$$

with associated price level $p_{t}=D_{t} / d$. Note that when the interest rate is driven to its lower bound, the policy regime effectively switches to the interest rate peg regime described earlier with all its associated indeterminacies. Condition (18) determines $d$ (and $k$ ) independently of $\theta$. In other words, open market operations that swap money for bonds do not matter, not even for the price level. ${ }^{9}$ 
Proposition 4 If $R^{b}=R^{m}$, then an increase in $\theta$ (an expansionary open market operation) has no effect on the capital spending $k=y-d$ or the price level $p_{t}=D_{t} /(y-k)$. The only effect is to increase excess reserves $m-\sigma k>0$, where $m=\theta d$. An increase in $R^{m}$ increases the real demand for debt $d$ and lowers the price level.

\section{DISCUSSION}

The previous results demonstrate that the comparative statics of both policy regimes above are identical. The only difference is whether we want to think of monetary policy as targeting an interest rate, permitting the money-to-debt ratio to accommodate itself to the chosen rate, or whether we want to think of monetary policy as choosing the composition of government debt, permitting the yield on government bonds to clear the bond market. When money is dominated in rate of return, the model delivers standard textbook results in terms of the consequences of monetary policy (actions that affect the policy rate $R^{b}$ ). When shocks drive the economy to a region in the parameter space where the ZLB is in effect $\left(R^{b}=R^{m}\right)$, the model delivers classic liquidity-trap effects (e.g., Krugman, 1998). Let me now use the model to interpret the U.S. macroeconomy and monetary policy before and after 2008.

\section{Typical Recession and Policy Response}

One way to generate a business cycle here is to assume that $x$ is subject to change over time. My preferred interpretation of $x$ is that it constitutes a news shock (Beaudry and Portier, 2014) realized at date $t$ but that affects productivity at date $t+1$. A decline in $x_{t}$ at date $t$ has the effect of reducing the demand for investment at date $t$ without changing the supply of output at date $t$ - that is, in this model, the real GDP is fixed at $Y_{t}=y+x_{t-1} f\left(k_{t-1}\right)$. As such, a decline in $x_{t}$ looks like a negative aggregate demand shock associated with an increasingly pessimistic outlook relating to the return to capital investment. ${ }^{10}$

Prior to 2008, the Fed's policy rate $\left(R_{t}^{b}\right)$ was above the ZLB $\left(R^{m}=1\right)$. Consider the economic contractions in the early 1990s and early 2000s. As with all recessionary events, these episodes were associated with bearish outlooks, which I want to think of here as a sequence of progressively lower realizations of $x$. By Proposition 3, the effect of a lower $x$ is to decrease investment demand, and hence decrease capital spending, which in turn leads to lower output. With longrun inflation anchored by the fiscal authority, such shocks can have only transitory effects on inflation, but they can have permanent effects on the price level. Absent an intervention, the effect of a lower $x$ is to cause a decline in the price level, which reflects an increase in the real demand for government securities $d=y-k$. A sequence of bad news shocks would therefore generate a deflationary episode $p_{t}>p_{t+1}>p_{t+2}$, even as expected inflation remains anchored at $\mu$.

Since $R^{b}>R^{m}$, there is scope for a monetary intervention that lowers $R^{b}$ either directly or indirectly through open market operations that expand the size of the Fed's balance sheet (i.e., an increase in $\theta$ ). By Proposition 3, the effect of such loosening of monetary policy is to stimulate capital spending, thereby preventing output from falling as much as it would absent the intervention. As well, another effect of the same intervention to stabilize the price level. 


\section{Figure 2}

\section{Treasury Yield and Money-to-Debt Ratio}

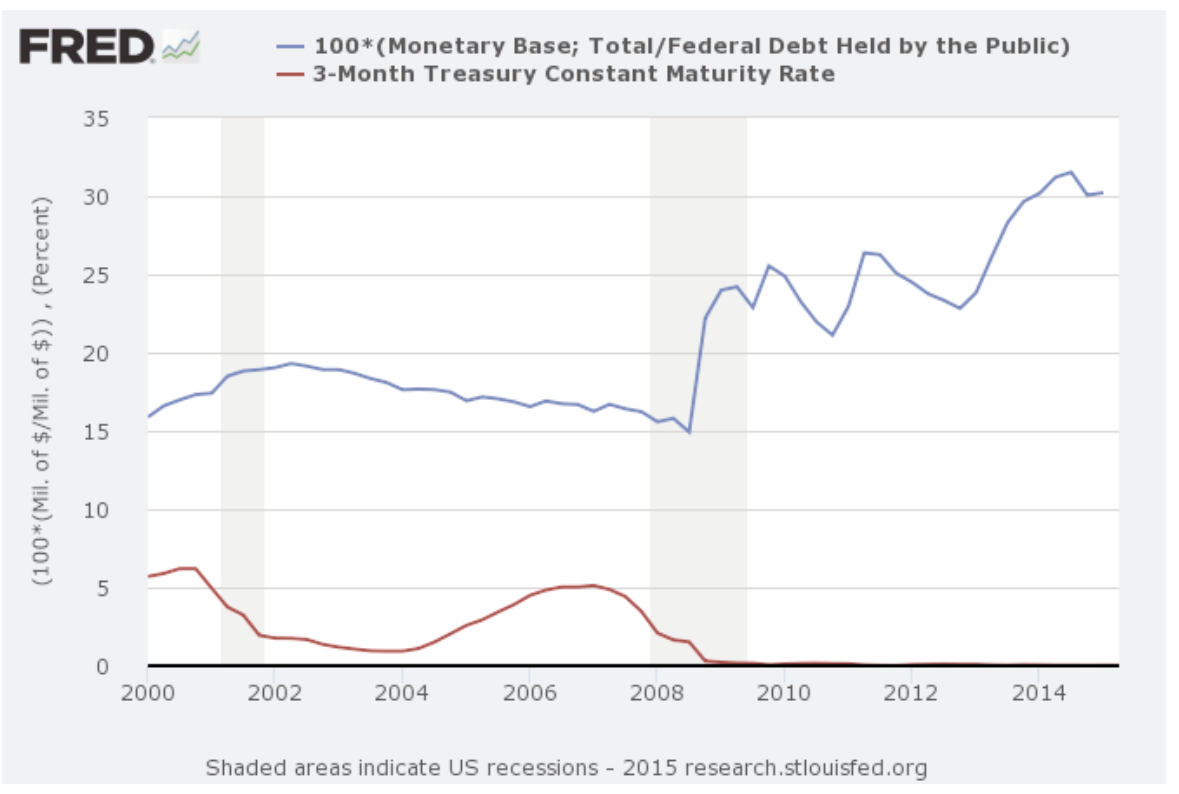

SOURCE: FRED ${ }^{\circledR}$, Federal Reserve Economic Database, Federal Reserve Bank of St. Louis; https://research.stlouisfed.org/fred2/graph/?g=1xeZ.

Incidentally, it is of some interest to ask what causes the interest rate to decline in a recession. To many observers, it appears that the Fed is causing the interest rate to decline, either directly through its policy rate or indirectly through its open market operations. As the previous analysis suggests, such a view is only partially correct. Consider, for example, the competitive equilibrium real interest rate in this economy absent any government $r=x f^{\prime}(y)$. In this case, a decline in $x$ will cause the interest to decline because (i) the supply of saving is fixed at $y$ and (ii) a lower $x$ implies a lower demand for capital. In other words, there are natural market forces at work pushing the interest rate lower in a recession that are independent of Fed actions. The question, really, is whether the Fed wants to accommodate these market forces. If it does not, the contraction in investment spending will be greater than it otherwise would be. In this sense, the Fed is not causing the interest rate to decline-it is simply accommodating market forces that "want" a lower interest rate.

\section{The Great Recession and Quantitative Easing}

The economic contraction of 2008 is unusual in at least two respects. First, it was unusually severe and, second, the market yield on U.S. Treasury securities fell to the interest rate on reserves. Consider Figure 2, which plots the 3-month Treasury yield and the ratio of base money to government debt held by the public. Note that the bond yield began to decline well 


\section{Figure 3}

\section{Monetary Base and the Price Level}

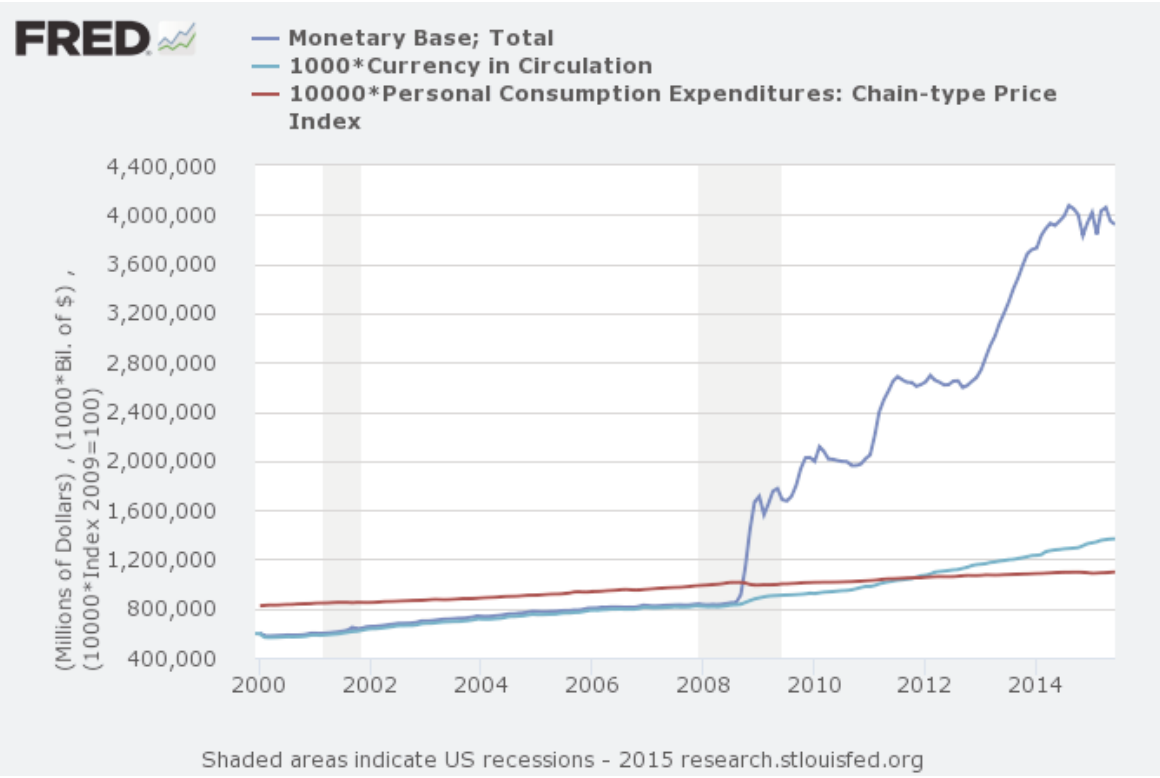

SOURCE: FRED ${ }^{\circledR}$, Federal Reserve Economic Database, Federal Reserve Bank of St. Louis; https://research.stlouisfed.org/fred2/graph/?g=1xf0.

before the start of the recession. This is consistent with deteriorating expectations (a decline in $x$ ) weakening investment demand and making bonds relatively more attractive. As the economic outlook continued to deteriorate throughout 2008, the economy contracted and yields continued to decline. With the failure of Lehman Brothers in the fall of 2008 and the economy on the verge of a financial crisis, the Federal Reserve announced the first of its large-scale asset purchase (LSAP) programs known as QE1. In the context of our model, one can interpret QE as a sharp increase in $\theta$. With these events, the yield on short-term Treasuries declined essentially to their lower bound, $R^{b} \backslash R^{m}$ (see Figure 2, late 2008) - an effect consistent with the model prediction (see Proposition 2). ${ }^{11}$

When $R^{b}=R^{m}$, Proposition 3 asserts that any further loosening of monetary policy (in the sense of increasing $\theta$ ) is completely innocuous: Increasing the supply of base money does not even influence the price level, a prediction consistent with the evidence (Figure 3 ). When $R^{b}=R^{m}$, the economy is in a liquidity trap. That is, the economy is satiated with liquidity and any further attempts to inject liquidity (withdraw bonds) will only lead investors to hold reserves as if they were bonds. The evidence presented in Figure 3 is not inconsistent with this prediction: Most of the increase in the supply of base money since late 2008 is, in fact, being held as excess reserves in the banking system.

Another striking development in 2008 was the sharp decline in the money multiplierthe ratio of a broad money aggregate relative to the monetary base. See Figure 4, which plots 


\section{Figure 4}

\section{The Money Multiplier}

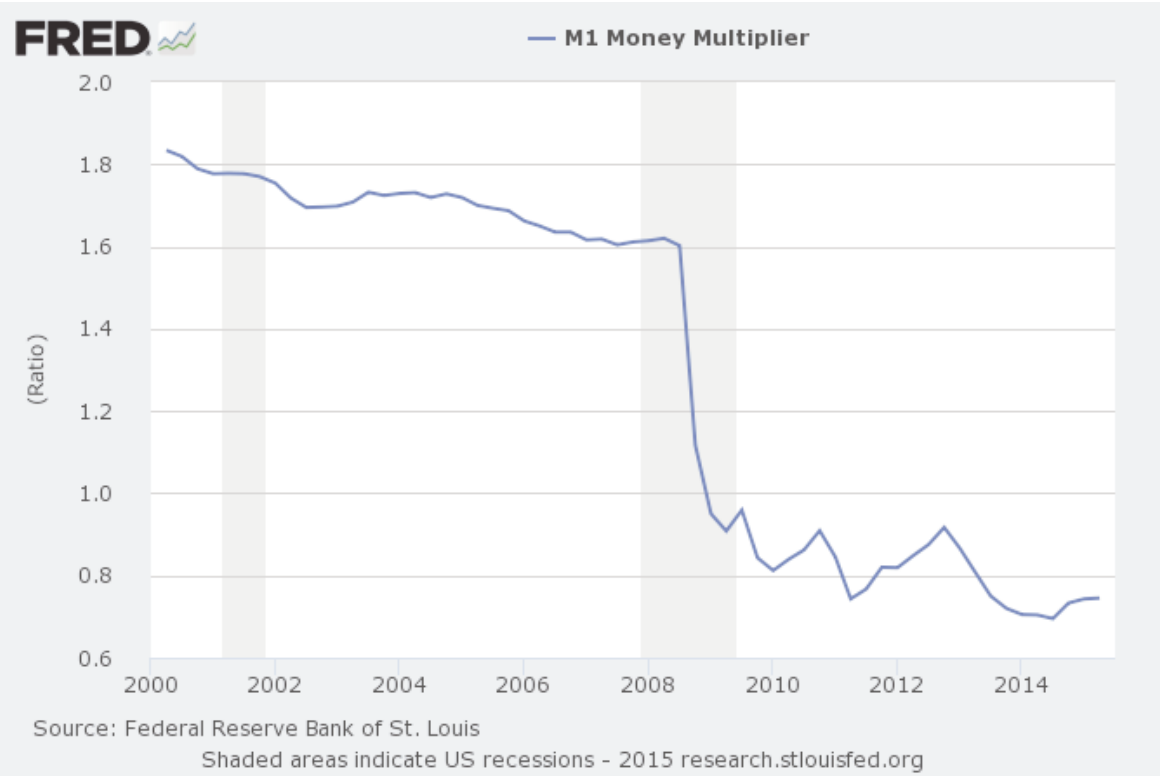

SOURCE: FRED ${ }^{\circledR}$, Federal Reserve Economic Database, Federal Reserve Bank of St. Louis; https://research.stlouisfed.org/fred2/graph/?g=1xf2.

M1 (roughly currency in circulation plus demand deposit liabilities) relative to the monetary base. The model developed above is not rich enough to make a sharp distinction between currency in circulation $M_{t}^{c}$ and bank reserves $M_{t}^{b}$, where $M_{t}=M_{t}^{c}+M_{t}^{b}$, so let me just assume that $M_{t}^{c}=\xi_{t} M_{t}$, where $0<\xi_{t}<1$ is exogenous. Suppose further that some exogenous fraction $0<\alpha_{t}<1$ of the economy's capital stock is intermediated by banks, so that demand deposit liabilities in the model equal $p_{t} \alpha_{t} k_{t}$. In this case, $\mathrm{M} 1$ is given by

$$
M 1_{t}=\xi_{t} M_{t}+p_{t} \alpha_{t} k_{t}
$$

Market clearing requires $p_{t}=D_{t} / d_{t}$, which, when substituted into the expression above and after some manipulation, yields

$$
\left[\frac{M 1_{t}}{M_{t}}\right]=\xi_{t}+\alpha_{t}\left(\frac{k_{t}}{y-k_{t}}\right)\left(\frac{1}{\theta_{t}}\right) .
$$

Thus, holding fixed the parameters $\xi_{t}, \alpha_{t}$, and $\theta_{t}$, an exogenous bad news shock (a sudden decline in $x$ ) is predicted (by Proposition 2) to cause a sharp decline in the money multiplier. The intuition is simple: The contraction in investment demand leads to a proportional decline in bank financing. Incidentally, since $p_{t}=D_{t} /(y-k)$, the same shock induces a decline in the 
price level (ceteris paribus), which did in fact occur and arguably would have been much more severe had $D_{t}$ not expanded at nearly the same time. Once the economy is at the $\operatorname{ZLB}\left(R_{t}^{b}=R^{m}\right)$, the theory predicts that monetary policy in the form of changes in $\theta_{t}$ has no real or nominal effects except, as condition (19) reveals, on the money multiplier. The observed decline in the U.S. money multiplier since 2008 can then be explained as the consequence of the Fed's continued QE programs at the ZLB.

Of course, if monetizing a greater fraction of government debt is as innocuous as Proposition 3 suggests, then what are the rationales for the Fed's QE2 and QE3 programs? One answer is that the conditions stated in Proposition 3 are extreme: They describe a circumstance in which government bonds are literally perfect substitutes for interest-bearing cash reserves. In reality, the Fed's LSAP programs have included nontraditional securities-for example, higheryielding longer-dated government bonds as well as agency debt. ${ }^{12}$ Technically then, one might expect some effect, but one that is likely to be small given the historically low yields that presently characterize these nontraditional securities. If so, then this would explain the difficulty encountered by economists in identifying the quantitative effects of the Fed's LSAP programs (e.g., Thornton, 2014).

\section{Why Is Inflation So Low?}

Figure 5 plots the PCE inflation rate, the short-term nominal interest rate (the effective federal funds rate), and the real GDP growth rate since 2007. According to these data, economic growth has returned to pre-recession levels, the nominal interest rate is close to zero, and yet the inflation rate remains stubbornly below the Fed's 2 percent target. According to standard Phillips curve reasoning, accelerating growth should cause inflation to go up, not down. Is there a way to rationalize this observation?

In the earlier specification of policy, I assumed that the fiscal authority mechanically chooses to grow its nominal debt at rate $\mu$. While this policy alone does not pin down the price level, it does pin down the expected growth path of the price level-that is, it determines the expected rate of inflation. For the case in which $R^{b}=R^{m}$, monetary and fiscal policy together then determine the real rate of return on government debt $R^{m} / \mu$, which, through the Fisher equation (15), then determines the equilibrium level of capital spending; that is,

$$
x f^{\prime}(k)=\frac{R^{m}}{\mu} .
$$

An alternative specification of fiscal policy is that it permits its nominal debt to grow passively at the rate at which it is demanded. In conventional infinitely lived agent models, the real interest rate $r=x f^{\prime}(k)$ is determined independently of monetary policy. In such a scenario, an improvement in the economic outlook (an increase in $x$ ) has the effect of increasing the real rate of interest. Since the nominal interest rate $R^{m}$ is determined by policy, the Fisher equation (20) implies that the inflation rate must decline to satisfy the no-arbitrage condition equating the risk-adjusted real returns on capital and bonds. Thus, this is one possible explanation for why inflation declines as the economy improves. Andolfatto and Williamson (2015) describe 


\section{Figure 5}

\section{Output, Inflation, and the Interest Rate}

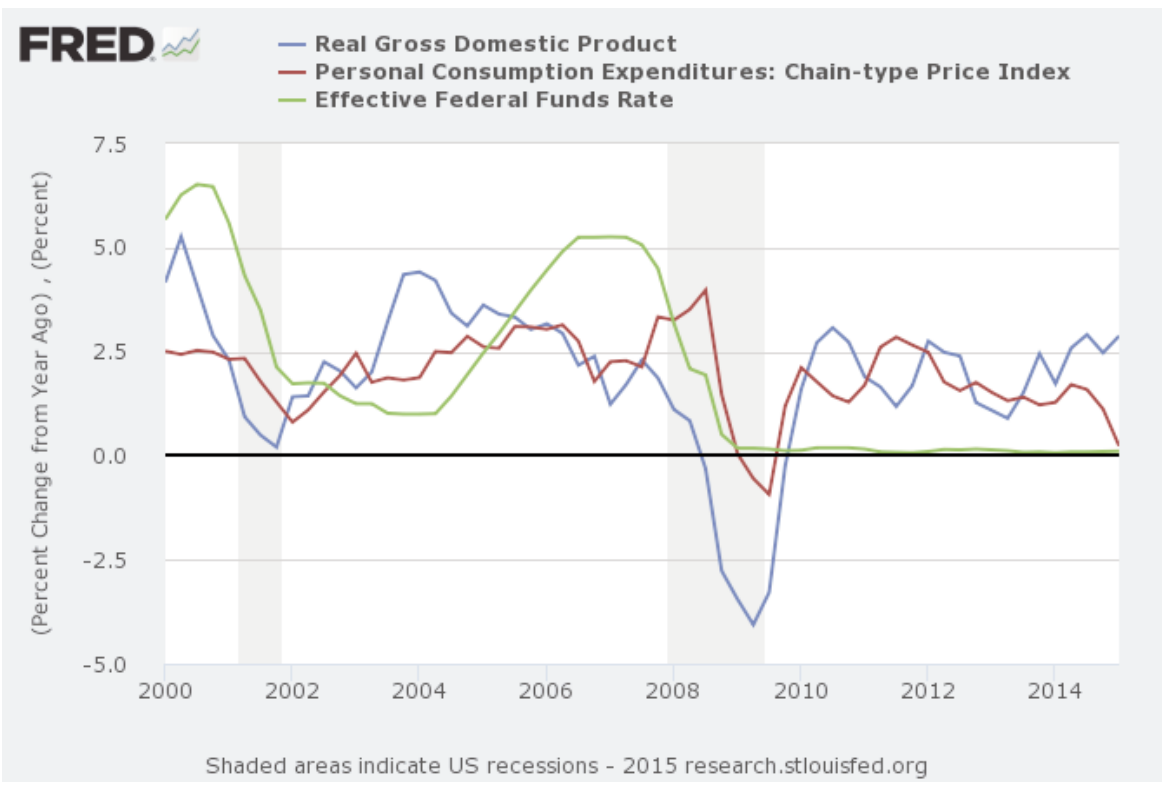

SOURCE: FRED ${ }^{\circledR}$, Federal Reserve Economic Database, Federal Reserve Bank of St. Louis; https://research.stlouisfed.org/fred2/graph/?g=1xf1.

a similar mechanism triggered by financial sector healing that relaxes debt constraints following a crisis. In both cases, the critical assumption is that the fiscal authority grows its nominal debt to accommodate the market clearing inflation rate.

This alternative specification of fiscal policy in my overlapping-generations setting, however, introduces a real indeterminacy along the lines of Sargent and Wallace (1985). Technically, any $(k, \mu)$ pair satisfying $0<k \leq y$ is consistent with equilibrium. Since growth in the demand for nominal debt depends, in part, on how the price level is expected to grow, we have a situation in which private-sector inflation expectations can be self-fulfilling, with the fiscal authority expanding the supply of nominal debt to accommodate whatever inflation rate people choose to focus on. This indeterminacy implies that the economy may get stuck at a level of real GDP that is too high or too low relative to some criterion that policymakers judge desirable. ${ }^{13}$ The notion that the economy might get stuck in a suboptimal equilibrium is a key insight in Keynes (1936). ${ }^{14}$ Farmer (2013) is an important modern proponent of this view. Thus, even if the economy returns to its long-run real growth rate (in this model, zero), the economy may remain mired in a secular stagnation where economic activity is depressed relative to its potential.

A final observation in regard to the relationship between inflation and interest rates is that condition (20) is consistent with a perpetually negative real rate of interest and a strictly posi- 
tive rate of inflation. This type of relationship is not consistent in conventional infinitely lived agent models. In this class of models, the real interest rate is strictly positive and invariant to policy. Consequently, a monetary policy based on a Friedman rule $\left(R^{m}=1\right)$ must imply deflation $\mu<1$. Conventional models modified to permit transactional debt that (owing to a shortage of good collateral assets) incorporate a liquidity premium can, however, accommodate the evidence (again, see Andolfatto and Williamson, 2015, for an example).

\section{Monetary Policy Going Forward}

Monetary policy in the United States since the end of the Great Recession has been characterized by a policy rate driven essentially by the IOER $R^{m}=1.0025$ and a balance sheet that is over four times larger than before the financial crisis, with most Fed liabilities existing as excess reserves in the banking system. As the real economy continues to improve, albeit at a slower pace than many have hoped for, and with inflation only 50 basis points below target, the Fed is preparing for liftoff-the date at which circumstances warrant increasing the policy rate. These circumstances evidently include continued improvement in the labor market and evidence that PCE inflation is unmistakably making its way back to its 2 percent target. ${ }^{15}$ Ultimately, the plan (or desire) is to normalize monetary policy, which the Fed describes as follows ${ }^{16}$ :

Monetary policy normalization refers to the steps the Federal Open Market Committee (FOMC) will take to remove the substantial monetary accommodation that it has provided to the economy during and in the aftermath of the financial crisis that began in 2007 . Specifically, monetary policy normalization refers to steps to raise the federal funds rate and other short-term interest rates to more normal levels and to reduce the size of the Federal Reserve's securities holdings and to return them mostly to Treasury securities, so as to promote the Federal Reserve's statutory mandate of maximum employment and price stability. The Committee plans to continue to use the federal funds rate as its key policy rate during the normalization process and to continue to set a target range for the funds rate when it begins to remove policy accommodation and for some time thereafter. When the Committee begins to normalize policy, it will raise the target range for the federal funds rate. This tightening of policy will be transmitted to other short-term interest rates and affect broader financial conditions in the economy.

How close is the U.S. economy to normal? By some metrics-for example, the 5.5 percent civilian unemployment rate-the U.S. economy seems not too far from normal. On the other hand, the expected real rate of return on short-maturity U.S. debt is negative 2 percent, substantially below its historical average of 2 percent.

As a practical matter, it is difficult to determine conclusively whether normality has been achieved. However, the model developed above can help shed some light on this question by providing a set of diagnostics. Think of the federal funds rate as $R_{t}^{b}$, which was over 5 percent prior to the crisis (see Figure 5). Also prior to the crisis, IOER was zero $\left(R^{m}=1\right)$ and excess reserves were zero as well. This state of affairs accords well with our theory, which predicts zero excess reserves when $R_{t}^{b}>R^{m}$. A combination of depressed economic conditions (lower $x$ ) together with a highly expansionary monetary policy (higher $\theta$ ) then drove the traditional policy rate down to $R^{m}$, which was raised in 2008 from zero to 25 basis points. ${ }^{17}$ The diagnostic 
is this: If the economy has indeed returned to normal (in the sense of $x$ returning to its precrisis level), why hasn't the price level inflated in proportion to the expansion in the base money supply?

Two facts-the price level continuing to grow at a rate even less than the targeted inflation rate and the large quantities of excess reserves still held in the banking sector-suggest that economic conditions have not returned to normal, at least not along some important dimensions. Given a fixed $R^{m} / \mu$, condition (20) suggests that the telltale sign of a normalizing economy (an increasingly optimistic outlook as parameterized by increases in $x$ ) should be robust growth in the level of capital spending (with a corresponding expansion in bank lending, to the extent that investment is bank financed) and positive price-level surprises (even as longterm inflation expectations remain anchored at $\mu$. The Fed is presumably primed to lift off once it sees strong evidence of this type of price-level movement.

\section{Monetary Policy with Excess Reserves}

While the FOMC passage quoted earlier alludes to the idea of reducing the size of the Fed's security holdings, there seems to be little desire to embark on this path in the early stages of liftoff. ${ }^{18}$ Thus, for at least the foreseeable future, the Fed will conduct its policy in the context of a large balance sheet and excess bank reserves. Its policy tool in this scenario is essentially the interest it pays on reserves, $R^{m} .{ }^{19}$ Theoretically, the stationary equilibrium associated with an interest rate peg is unstable and induces price-level indeterminacy. However, hyperinflationary outcomes can theoretically be avoided by assuming that interest rate policy depends on macroeconomic conditions along the lines described by Taylor (1993). Consider, for example, a Taylor rule given by

$$
\ln R_{t}^{m}=\max \left\{\phi \ln \Pi_{t}+(1-\phi) \ln \Pi^{*}+\ln r_{t}, \ln \hat{R}\right\},
$$

where $r_{t}=x f^{\prime}\left(k_{t}\right)$ is a measure of the real rate of interest, $\phi>0$ is a parameter that governs how strongly the policy rate (here, interest on reserves) adjusts to deviations in inflation from target $\Pi^{*}$, and $\hat{R}$ is the interest rate floor. The max operator restricts the policy rate from falling below the interest rate floor. ${ }^{20}$

Consistent with the literature on Taylor rules, I assume that the fiscal authority passively accommodates inflation expectations, so that $\mu_{t+1}=\Pi_{t+1}^{e}$, where $\Pi_{t+1}^{e}$ denotes the expected inflation rate. Along a perfect foresight path, $\Pi_{t+1}^{e}=\Pi_{t+1}=\mu_{t+1}$. As explained earlier, this specification of fiscal policy introduces a real indeterminacy, which can be resolved in a couple of ways. First, we could assume that $0<k_{t}<y$ is determined exogenously, in which case inflation expectations are determined by the Fisher equation (20); that is,

$$
\ln \mu_{t+1}=\ln R_{t}^{m}-\ln \left[x f^{\prime}\left(k_{t}\right)\right] .
$$

Second, we could assume that inflation expectations are formed exogenously, in which case condition (22) determines the equilibrium level of capital spending. In either case, I combine (22) with (21), invoking $\Pi_{t}=\mu_{t}$, and assuming $k_{t}=k$ to form 


$$
\ln \mu_{t+1}=\left\{\begin{array}{ccc}
\phi \ln \mu_{t}+(1-\phi) \Pi^{*} & \text { if } & \ln R_{t}^{m}>\ln \hat{R} \\
\ln \hat{R}-\ln \left[x f^{\prime}(k)\right] & \text { if } & \ln R_{t}^{m}=\ln \hat{R}
\end{array} .\right.
$$

The behavior for inflation described by (23) depends critically on whether the parameter $\phi$ is greater or less than unity. If $0<\phi<1$, then there is a unique steady-state inflation rate that corresponds to the target rate $\Pi^{*}$. Moreover, along the perfect foresight path, the inflation rate approaches the target rate monotonically from any initial condition $\mu_{0}=p_{0} / p_{-1}$, with $p_{0}=D_{0} /\left(y-k_{0}\right)$, where $0<D_{0}<\infty$ is determined exogenously by the fiscal authority. ${ }^{21}$ If $\phi>1$, then there are two steady states, one of which is the one just described. The second steady state occurs when the nominal interest is at its ZLB, in which case the equilibrium inflation rate falls perpetually short of its target. As stressed by Benhabib, Schmitt-Grohé, and Uribe (2001), this latter low inflation equilibrium is stable and the intended equilibrium is unstable when the Taylor principle holds-this is, when $\phi>1$.

Back in 2010, St. Louis Fed President James Bullard wondered out loud whether the Fed's low interest policy might lead to a disinflationary dynamic along the lines theorized by Benhabib, Schmitt-Grohé, and Uribe (2001). ${ }^{22}$ If this interpretation is correct, then the Fed's aggressive $(\phi>1)$ lowering of its policy rate may have resulted in the unintended steady state. From (23), we have

$$
1<\mu=\frac{\hat{R}}{x f^{\prime}(k)}<1.02=\Pi^{*}
$$

where $\hat{R}=1.0025$ (the IOER rate at present).

If the fiscal authority has not anchored $\mu$, then any combination of $(\mu, k)$ satisfying $\mu=\hat{R} /\left[x f^{\prime}(k)\right]$ is consistent with equilibrium. In particular, a secular stagnation outcome is possible in which the level of economic activity (measured here by $k$ ) is less than normal—even if $x$ has returned to normal. In this hypothetical world, an improvement in the economic environment brought about by, say, an increase in $x$ has the effect of increasing the real interest rate (assuming that $k$ either remains the same or does not expand so far as to keep the marginal product of capital at its initial level). The effect of this development is to put downward pressure on the inflation rate. According to the Taylor rule, the prescription for a decline in inflation is to reduce the nominal interest rate aggressively or, barring this possibility, to keep it at its lower bound for the indefinite future. Moreover, while a decline in $x$ will have the effect of raising the inflation rate, the associated reduction in output is likely to warrant keeping (in the eyes of policymakers) the interest rate at zero in this case as well. In this manner, policymakers may find themselves stuck in a Japanese-style low inflation and low interest rate equilibrium.

Schmitt-Grohé and Uribe (2014) use a Taylor rule like (21) to generate a low inflation rate equilibrium along with a form of nominal wage rigidity that associates such an equilibrium with a suboptimal level of output. These authors propose a monetary policy to lift the economy out of its slump. In particular, they advocate raising the nominal interest rate $R_{t}^{m}$ to its intended target $R^{*}=\Pi^{*} r^{*}$ for an extended period. ${ }^{23}$ The authors claim that such a policy will boost infla- 
tion expectations, which, in their model, overcomes the assumed nominal wage rigidity and reestablishes the intended steady state as an equilibrium outcome.

Formally, the policy recommendation of Schmitt-Grohé and Uribe (2014) entails the Fed switching from $\phi>1$ to $\phi<1$ in the Taylor rule (21). Such a policy change would have the same inflation consequences in the model above. It is worth emphasizing that this result relies heavily on two critical assumptions. First, it depends critically on rational expectations. In particular, consider the Fisher equation (22): If the real interest rate $x f^{\prime}(k)$ is fixed, then an increase in the policy rate must be associated with an increase in inflation expectations. Second, to accommodate these expectations, it is absolutely critical for the fiscal authority to stand willing to expand its nominal debt issue. One may reasonably question whether these assumptions hold even approximately in reality.

In any case, even if these two assumptions are met, the effect of changing monetary policy in the manner just described depends critically on what other assumptions one makes in terms of how the economy operates. For example, the same change in policy in the model I described earlier will have no effect on real economic activity. Along the transition path, the nominal interest rate rises one for one with expected inflation, leaving the real interest rate (and hence the marginal product of capital) unchanged. Admittedly, this is a very special case, but it illustrates the caution one should use when assessing the predictions of economic models.

An alternative specification of policy is to assume, as I did earlier, that $\mu$ is determined as an explicit target by the fiscal authority. In this case, the Fisher equation (22) implies

$$
\ln \left[x f^{\prime}\left(k_{t}\right)\right]=\ln R_{t}^{m}-\ln \mu .
$$

If inflation (and inflation expectations) are anchored in this manner, then the effect of raising the policy rate $R_{t}^{m}$ is to increase the real rate of interest, thereby depressing capital spending. Recall from Proposition 3 that the effect of raising the interest rate on reserves in this manner (and in a liquidity-trap situation) is to put downward pressure on the price level (without affecting the expected rate of inflation going forward). This is the sense in which a premature liftoff may be undesirable. A return to normality brought about by an increase in the economic outlook $(x)$, on the other hand, has the effect of increasing capital spending and the price level. This is the circumstance in which liftoff may be desirable, which is why in practice the Fed is waiting for the signal of significant price-level pressure before it begins to raise its policy rate.

\section{CONCLUSION}

I began this article by posing a few questions. I now reflect on the answers to these questions suggested by the theory described here.

First, why did interest rates plummet so precipitously in 2008? The complete answer is not "the Fed did it." There are natural market forces at work that drive interest rates lower when the economic outlook is depressed. Whether these diminished expectations were the by-product of a rational pessimism or an irrational fear is irrelevant with regard to the effect on market 
interest rates. In such conditions, people want to save more and firms want to invest less. Both effects lower the real rate of interest. As for the Fed, one way to view its policy response is that it did everything it could to accommodate the market's desire for lower rates. Had the Fed not accommodated this desire, the effect would have been to keep real interest rates at an excessively high level, which would have exacerbated the contraction in spending brought about by the pessimistic outlook.

Second, I asked why the massive increase in base money appears to have no noticeable effect on the price level or inflation. The answer is that, with the Fed's policy rate driven down to its effective lower bound, increases in the supply of low-interest-bearing money for the purpose of purchasing low-interest-bearing debt are largely innocuous. The effect is just to relabel equivalent government liabilities from Treasury money to Fed money. The rise in total government debt during the crisis undoubtedly did have an impact on stabilizing the price level during the worst period of the financial crisis. But the QE programs initiated by the Fed did nothing to increase the total debt-they just had the effect of altering the composition of the debt and increasing the supply of excess reserves in the banking system. In this liquidity-trap scenario, it is not surprising that an increase in the base money supply has had little effect on inflation or the price level.

Third, does the fact that most of this new money sits as excess reserves in the banking system portend an impending inflationary episode-an event that the Fed might have trouble controlling? The short answer to this question is no. At least, not necessarily. The Fed has several tools at its disposal. If undue price-level pressure is detected, one option would be to engage in asset sales (that is, reverse the QE programs). Alternatively, the Fed could raise the IOER rate to enhance the real demand for reserve balances. In practice, tightening monetary policy in either of these manners is always controversial and subject to political scrutiny. But there is little question that the Fed has the tools at its disposal to keep inflation in check.

Fourth, I asked why inflation seems so low and whether inflation might continue to drift lower as interest rates remain low, replicating the experience of Japan over the past two decades. In the context of my model, long-run inflation is ultimately determined by the fiscal authority. In a liquidity-trap scenario, the central bank cannot affect inflation even in the short run. So the question is whether the enhanced demand for government debt will continue moving forward and whether the fiscal authority might show any willingness to increase primary government budget surpluses moving forward. I will not speculate on the prospect of future budget surpluses, but it seems safe to say that the demand for government debt is likely to abate as world economic conditions improve. When (or if) this happens, inflation is likely to creep back up to its target rate.

Finally, I asked what, if anything, the Fed should do in present circumstances. The Fed's congressional mandate is to use whatever tools it has at its disposal to keep inflation low and stable and to promote real economic activity. Since the end of the Great Recession, U.S. PCE inflation has remained low and stable, perhaps even too low by some tastes. The model suggests that the Fed's control over inflation (as opposed to the price level) is limited in a liquiditytrap scenario, but, of course, actual economic conditions do not correspond precisely to a pure liquidity trap. In any case, even in a liquidity trap the theory presented here shows how the 


\section{Andolfatto}

Fed's IOER rate can be used to blunt undue price-level pressure. The theory also suggests that keeping the policy rate low in present circumstances is consistent with promoting real economic activity and keeping inflation low and stable.

\section{NOTES}

1 The three QE programs to date are QE1 (December 2008-March 2010), QE2 (November 2010-June 2011), and QE3 (September 2012-October 2014).

2 The assumption that the lump-sum tax/transfer falls solely on the old is not innocuous. Among other things, it will imply that helicopter drops of nominal assets are neutral. This is because only the old possess nominal assets at the time of a monetary injection, so lump-sum transfers of money to them end up increasing everyone's money balances in proportion to their holdings.

3 I do not distinguish between cash and central bank reserves in this article, although it would be interesting to extend the analysis along this dimension.

4 I do not assume here that the young deposit their entire endowment with the bank because it would have the effect of rendering the demand for real money balances exogenous (when binding); that is, $m_{t}=\sigma y$. This defect is easily rectified, however, if I assume that the young value consumption so that deposits do not correspond to $y$.

It would also be of some interest to experiment with other specifications_-for example, requirements that some minimal amount of bonds also be held in reserve. The effect of an open market operation in this case would depend on which set of reserve constraints is binding.

5 Friedman (1960) advocated paying interest on (required) reserves to alleviate the implicit tax associated with a binding reserve requirement.

6 In a related model, Sargent and Wallace (1985) assert the existence of a continuum of stationary equilibria satisfying a restriction similar to (14); see their equation 6 (p. 283). The same indeterminacy exists here if $A$ is left free, in which case policy is assumed to adjust passively to private-sector expectations and behavior.

7 Paths with the property $d_{t} \rightarrow \infty$ are ruled out as equilibria because they violate feasibility: $d_{t} \leq y$ for all $t$.

8 Thus, hyperinflation is possible even with a contracting supply of money $(\mu<1)$.

9 I remind readers that by an "open market operation,"I mean a swap of bonds for reserves for a given level of debt $D_{t}$. If the open market operation consists instead of financing a given ratio of additional debt $D_{t}+\Delta D_{t}$, then there would be a price-level effect, although in this model, a surprise injection of nominal debt is neutral.

${ }^{10}$ Note that for positive analysis, it matters not whether expectations are rational. Pessimism here manifests itself in exactly the same way, regardless of its source. This distinction would, of course, matter for normative analysis.

11 The reality is a little more complicated than what the model suggests. In particular, the QE1 intervention was largely in the form of lending against non-Treasury collateral. Moreover, the QE2 and QE3 interventions included purchases of agency debt. It is nevertheless true that the supply of base money relative to government debt rose, as Figure 2 shows.

${ }^{12}$ Agency debt consists mainly of new (not legacy) AAA-rated mortgage-backed securities issued by Fannie Mae and Freddy Mac.

${ }^{13}$ One such measure is the Congressional Budget Office concept of potential GDP; see "A Summary of Alternative Methods for Estimating Potential GDP" (http://www.cbo.gov/sites/default/files/03-16-gdp.pdf).

${ }^{14}$ Keynes (1936, Chap. 18) states "In particular, it is an outstanding characteristic of the economic system in which we live that, whilst it is subject to severe fluctuations in respect of output and employment, it is not violently unstable. Indeed it seems capable of remaining in a chronic condition of subnormal activity for a considerable period without any marked tendency either towards recovery or towards complete collapse."

15 See the March 18, 2015, Federal Open Market Committee policy statement (http://www.federalreserve.gov/newsevents/press/monetary/20150318a.htm). 
${ }^{16}$ See "What Does the Federal Open Market Committee Mean by 'Monetary Policy Normalization?"' (http://www.federalreserve.gov/faqs/what-does-the-fomc-mean-by-monetary-policy-normalization.htm).

${ }^{17}$ In fact, the federal funds rate and the yield on very short-term Treasuries is presently below $R^{m}$, a phenomenon that is evidently a by-product of the fact that government-sponsored agencies such as Fannie Mae and Freddy Mac are not permitted to earn interest on their reserve accounts.

18 The lack of desire to sell securities seems to be driven by the fear that any such announcement might lead to a sell-off in the bond market, disrupting financial markets and hindering the recovery. See Neely (2014) for a description of the 2013 taper tantrum event.

${ }^{19}$ At the date of liftoff, the Fed will in fact use an overnight reverse repo interest rate $R^{b} \leq R^{0} \leq R^{m}$ to induce the federal funds rate higher. In the event that the federal funds rate does not respond as desired, the Fed is likely to increase the IOER rate in its attempt to maintain monetary policy control.

20 Technically, I could allow negative nominal interest rates; see Kimball (2012). All that is important here is that a lower bound exists not too far below zero.

${ }^{21}$ That is, I assume that the fiscal authority chooses the initial supply of nominal debt but thereafter supplies nominal debt perfectly elastically to accommodate market demand.

22 See Bullard (2010).

${ }^{23}$ Here, $r^{*}$ corresponds to some natural rate of interest (e.g., $r^{*}=x^{*} f^{\prime}\left(k^{*}\right)$, where $x^{*}$ and $k^{*}$ correspond to normal levels of productivity and capital spending, respectively).

\section{REFERENCES}

Andolfatto, David. "Monetary Implications of the Hayashi-Prescott Hypothesis for Japan." Monetary and Economic Studies, December 2003, 21(4), pp. 1-20.

Andolfatto, David and Williamson, Stephen. "Scarcity of Safe Assets, Inflation, and the Policy Trap." Journal of Monetary Economics, July 2015, 73, pp. 70-92.

Beaudry, Paul and Portier, Franck. "News-Driven Business Cycles: Insights and Challenges." Journal of Economic Literature, December 2014, 52(4), pp. 993-1074.

Benhabib, Jess; Schmitt-Grohé, Stephanie and Uribe, Martín. "The Perils of Taylor Rules." Journal of Economic Theory, January 2001, 96(1-2), pp. 40-69.

Bullard, James. "Seven Faces of 'The Peril!'” Federal Reserve Bank of St. Louis Review, September/October 2010, 92(5), pp. 339-52.

Farmer, Roger. "Animal Spirits, Financial Crises and Persistent Unemployment." Economic Journal, May 2013, 123(568), pp. 317-40.

Friedman, Milton. A Program for Monetary Stability. New York: Fordham University Press, 1960.

Keynes, John M. The General Theory of Employment, Interest and Money. London: Palgrave Macmillan, 1936.

Kimball, Miles. "How Paper Currency Is Holding Back the U.S. Recovery." Quartz, November 5, 2012; http://qz.com/21797/the-case-for-electric-money-the-end-of-inflation-and-recessions-as-we-know-it/.

Krugman, Paul. "It's Baaack: Japan's Slump and the Return of the Liquidity Trap." Brookings Papers on Economic Activity, 1998, 29(2), pp. 137-87.

Neely, Christopher. "Lessons from the Taper Tantrum.” Federal Reserve Bank of St. Louis Economic Synopses, No. 2, January 27, 2014; http://research.stlouisfed.org/publications/es/14/ES_2_2014-01-28.pdf.

Samuelson, Paul A. "An Exact Consumption-Loan Model of Interest with or without the Social Contrivance of Money." Journal of Political Economy, December 1958, 66(6), pp. 467-82.

Sargent, Thomas and Wallace, Neil. "Interest on Reserves." Journal of Monetary Economics, May 1985, 15(3), pp. 279-90. 


\section{Andolfatto}

Schmitt-Grohé, Stephanie and Uribe, Martín. "The Making of a Great Contraction with a Liquidity Trap and a Jobless Recovery." Unpublished manuscript, Columbia University, November 27, 2014; http://www.columbia.edu/ mu2166/Making_Contraction/paper.pdf.

Smith, Bruce D. "Interest on Reserves and Sunspot Equilibria: Friedman's Proposal Reconsidered." Review of Economic Studies, January 1991, 58(1), pp. 93-105.

Taylor, John B. “Discretion versus Policy Rules in Practice." Carnegie-Rochester Conference Series on Public Policy, 1993, 39(1), pp. 195-214.

Thornton, Daniel L. "QE: Is There a Portfolio Balance Effect?" Federal Reserve Bank of St. Louis Review, First Quarter 2014, 96(1), pp. 55-72; http://research.stlouisfed.org/publications/review/2014/q1/thornton.pdf. 